\title{
Protective effect of quinacrine against glycerol-induced acute kidney injury in rats
}

\author{
Abdulrahman K. Al Asmari ${ }^{{ }^{*}}$, Khalid Tariq Al Sadoon², Ali Ahmed Obaid², Deivakadatcham Yesunayagam \\ and Mohammad Tariq $^{1}$
}

\begin{abstract}
Background: Acute kidney injury (AKI) is a serious clinical problem with high rate of mortality and morbidity. Currently used prophylactic and therapeutic strategies to address AKI are limited and warrant further studies. In the present study an attempt was made to investigate the effect of quinacrine, a phospholipase A2 inhibitor against glycerol induced AKI in rats.
\end{abstract}

Methods: Adult female Wistar rats were divided in to five groups. After $24 \mathrm{~h}$ of water deprivation rats in groups 3,4 and 5 received an intraperitoneal injection of quinacrine $(3 \mathrm{mg} / \mathrm{kg}, 10 \mathrm{mg} / \mathrm{kg}$ and $30 \mathrm{mg} / \mathrm{kg}$ of body weight respectively). Thirty minutes after the first injection of quinacrine animals in groups 3, 4 and 5 received an intramuscular injection of $25 \%$ glycerol $(10 \mathrm{ml} / \mathrm{kg}$ of body weight). The animals in group 2 received $25 \%$ glycerol $(10 \mathrm{ml} / \mathrm{kg}$ of body weight) only whereas rats in group 1 served as control. The quinacrine administration was continued once daily for three days, on the fourth day animals were sacrificed, blood and kidney were collected for various biochemical and histopathological studies.

Results: Glycerol treatment produced significant renal structural abnormalities and functional impairment (increased urea and creatinine). Increase in myeloperoxidase (MPO) and malondialdehyde (MDA) clearly suggested the involvement of oxidative stress and neutrophilic activity following glycerol administration. Quinacrine dose dependently attenuated glycerol induced structural and functional changes in kidney.

Conclusion: The reversal of glycerol induced AKI by quinacrine points towards a role of phospholipase A2 (PLA2) in the pathogenesis of renal injury. The result of this study suggests that quinacrine may offer an alternative mode of treatment for AKI.

Keywords: Glycerol, Acute kidney injury, Quinacrine, Phospholipase A2, Oxidative stress, Inflammation

\section{Background}

Acute kidney injury, previously termed acute renal failure, is associated with increased mortality, prolonged hospital stay, and accelerated chronic kidney disease. Over the past few decades, dramatic rises in the incidences of AKI have been reported. Despite the reversibility of AKI in the patients who survive, mortality from AKI remains high (over 50\%) [1]. In the recent years, the search for effective therapy to accelerate recovery and attempts to prevent AKI have attracted much attention. One of the most commonly used experimental models

\footnotetext{
*Correspondence: adbulrahman.alasmari@gmail.com

${ }^{1}$ Scientific Research Centre, Prince Sultan Military Medical City, Riyadh, Saudi Arabia

Full list of author information is available at the end of the article
}

for studying AKI is the rat receiving a single intramuscular injection of glycerol, which induces rhabdomyolysis $[2,3]$. Rhabdomyolysis-induced myoglobinuric renal failure accounts for about $10-40 \%$ of all cases of AKI [4]. Moreover during the time of war [5] and natural disaster [6] rhabdomyolysis induced myoglobinuric injury reached an epidemic state. Glycerol-induced AKI in rodents is mediated by renal ischemia and myoglobin nephrotoxicity [7, 8]. In glycerol-induced AKI, redox cycle, the myoglobin heme induces oxidative stress and lipid peroxidation of the proximal tubular cell, triggers the release of a series of mediators, including cytokines and chemokines, leading to leukocyte activation, resulting in tubular necrosis in the cortical area [9-12]. However the precise molecular mechanism of glycerol induced 
nephrotoxicity is still unclear. Some recent studies suggested that glycerol induced ischemic insult to the renal tissue may result in derangement of cellar phospholipid membranes, which may trigger a sequence of biochemical events leading to irreversible cell injury, presumably due to enhanced generation of oxygen derived free radicals and activation of tissue phospholipases [13, 14].

There is ample evidence which suggest that the critical events determining the course of AKI develop from damage to plasma and subcellular membranes [15]. Phospholipids besides providing the major structural framework for cell membranes [16] participate in the regulation of membrane enzyme activity, permeability and hormone activation [17-20]. Ischemic injury has been associated with depletion of major phospholipids and accumulation of phospholipid by-products in liver, heart and renal cortex [21-23]. The activation of membrane phospholipases, especially phospholipase PLA2 has been shown to play a pivotal role in the critical early events in the pathogenesis of ischemic cell injury [24]. Moreover increased PLA $\mathrm{P}_{2}$ activity also leads to the release of arachidonic acid (AA) from membrane phospholipids [25] which is the precursor for the biosynthesis of vasoactive prostaglandins and leukotrienes [26]. A blockade of $\mathrm{PLA}_{2}$ could result in the suppression of these important classes of vasoactive lipid mediators and may offer an attractive tool to understand the pathophysiology of cytotoxic chemicals and to design novel agents that could attenuate or prevent tissue injury. Hence, the present investigation is an attempt to study effect of quinacrine, a potent inhibitor of PLA 2 [27] on glycerol induced deleterious effects on renal structure and function in rats.

\section{Methods}

\section{Animals}

Animals were received from the Animal Facility Unit of Research Centre, Prince Sultan Military Medical City, Riyadh, Saudi Arabia. Forty adult female Wistar rats weighing $200 \pm 10 \mathrm{~g}$ were housed in a $12 \mathrm{~h}$ dark/light cycle animals facility with controlled temperature and humidity. Food and water were given ad libitum throughout the study.

\section{Drugs}

Quinacrine obtained from ICN Biochemical Inc, USA. Glycerol 99\%, Pentobarbital sodium and other chemical used for biochemical assays were purchased from Sigma Chemical Co., St. Louis., MO., USA.

\section{Experimental design}

The protocol suggested by Midhun et al. [28] was followed to study the effect of quinacrine on glycerol induced acute renal injury. The detail of groups, treatments and sacrificing protocol were tabulated in Table 1 . The rats were randomized and divided into five groups of eight animals each. The number of animals in each group were calculated according to the method described by Charan and Kanthria et al. [29] which is based on the value "Effect size (difference between mean of the groups) standard deviation taken from our earlier studies along with a power level $80 \%$ and significance level of $5 \%$ ".

After being water deprived for $24 \mathrm{~h}$, animals from group 1 and 2 received intraperitoneal injection of normal saline $(2 \mathrm{ml} / \mathrm{kg}$ of body weight), whereas group 3,4 and 5 received intraperitoneal injection of quinacrine at the dose of $3 \mathrm{mg} / \mathrm{kg}, 10 \mathrm{mg} / \mathrm{kg}$ and $30 \mathrm{mg} / \mathrm{kg}$ of body weight. After $30 \mathrm{~min}$ of first injection of quinacrine, rats in group 2,3,4 and 5 received a single intramuscular injection of $25 \%$ glycerol $(10 \mathrm{ml} / \mathrm{kg}$ body weight). Quinacrine injection (prepared freshly) was continued once daily for three days. Body weight, food and fluid intake were recorded daily at specific time. Twenty four hours after last injection of quinacrine all the rats were sacrificed under general anesthesia using intraperitoneal injection of pentobarbital sodium $(150 \mathrm{mg} / \mathrm{kg})$, blood was collected through heart puncture. The left side kidney was excised immediately, weighed, divided into four parts and stored in $-70{ }^{\circ} \mathrm{C}$ for biochemical analysis. The right kidney was fixed in $10 \%$ neutral buffered formalin for histological studies.

\section{Serum biochemical analysis}

All blood samples were allowed to clot at ambient temperature and centrifuged (3000 rpm for $10 \mathrm{~min}$ ) to harvest the serum. Serum biochemical parameters of blood urea nitrogen (BUN), creatinine (Scr) calcium $(\mathrm{Ca} 2+)$, magnesium, sodium, potassium and phosphorus levels were measured spectrophotometrically (APEL PD303S Japan) using the commercially available kits BUN (REF-020), Scr (REF-033 K), calcium (REF-022), magnesium (REF-050), sodium (REF-054 K), potassium (REF051), phosphorus (REF-046) from United Diagnostics Industry, Riyadh, Saudi Arabia.

Table 1 Drug treatment protocol

\begin{tabular}{llllll}
\hline Groups & Day-0 & Day-1 & Day-2 & Day-3 & Day-4 \\
\hline Control & WD & saline & saline & saline & Sacrificed \\
GLY 25\% (GLY) & WD & GLY & saline & saline & Sacrificed \\
QRN 3 mg/kg + GLY & WD & QRN + GLY & QRN & QRN & Sacrificed \\
QRN $10 \mathrm{mg} / \mathrm{kg}+$ GLY & WD & QRN + GLY & QRN & QRN & Sacrificed \\
QRN $30 \mathrm{mg} / \mathrm{kg}+$ GLY & WD & QRN + GLY & QRN & QRN & Sacrificed \\
\hline
\end{tabular}

Abbreviations: WD water deprived, QRN quinacrine, GLY glycerol 25\% 


\section{Determination of myeloperoxidase}

The level of neutrophil derive enzyme MPO activity in kidney was measured according to the methods of Barone et al. [30]. The kidney tissue was homogenized (1:20 wt/vol) in $5 \mathrm{mM}$ potassium phosphate buffer ( $\mathrm{pH}$ 6.0). The homogenate was centrifuged at $17000 \mathrm{~g}$ for $15 \mathrm{~min}$. at $4{ }^{\circ} \mathrm{C}$. After discarding the supernatant the pellet was extracted with $0.5 \%$ hexadecyltrimethylammonium bromide in $50 \mathrm{mM}$ potassium phosphate buffer ( $\mathrm{pH}$ 6.0). The sample was subjected to three freeze-thaw cycles, with sonication $\left(10 \mathrm{~s}, 25^{\circ} \mathrm{C}\right)$ between cycles. After sonication, the samples were incubated at $4{ }^{\circ} \mathrm{C}$ for $2 \mathrm{~min}$ and again centrifuged at $12500 \mathrm{~g}\left(15 \mathrm{~min}, 4^{\circ} \mathrm{C}\right)$. MPO activity in the supernatant was assayed by mixing $0.1 \mathrm{ml}$ of supernatant with $2.9 \mathrm{ml}$ of $50 \mathrm{mM}$ potassium phosphate buffer ( $\mathrm{pH} 6.0$ ) containing $0.167 \mathrm{mg} / \mathrm{mL}$ o-dianasidinedihydrochloride and $0.0005 \%$ hydrogen peroxide. The change in absorbance at $460 \mathrm{~nm}$ was measured for $3 \mathrm{~min}$ with an UV spectrophotometer (Shimadzu, UV-160A, Japan).

\section{Determination lipidperoxidation}

The level of thiobarbituricacid reactive substances (TBARS) as a method of lipid peroxidation in kidney tissue was measured according to the method described by Ohkawa et al. [31]. Approximately $0.5 \mathrm{~g}$ of kidney tissue was homogenized in $1.15 \%$ cold $\mathrm{KCl}$. After centrifugation at $3000 \mathrm{~g}$ for $5 \mathrm{~min}$, an aliquot of supernatant was mixed with $2 \mathrm{ml}$ of reaction mixture (containing 15\% trichloroacetic acid and $0.375 \%$ thiobarbituric acid solution in $0.25 \mathrm{~N} \mathrm{HCl}$ ) and heated for $5 \mathrm{~min}$ in a boiling water bath. The tubes were cooled at room temperature and centrifuged at $1000 \mathrm{~g}$ for $10 \mathrm{~min}$. The absorbance of supernatant was read at $535 \mathrm{~nm}$ against a blank that contained all reagents except homogenate. Tissue lipid peroxide levels were calculated as nanomoles of MDA, tetramethoxy propane was used as standard.

\section{Histopathological evaluation}

After recording the kidney weight and morphological examination, the kidney was fixed immediately in 10\% formalin, embedded in paraffin, sectioned at $3 \mu \mathrm{m}$ thickness and were stained with haematoxylin and eosin. The extent of tubular injury, dilatation, vacuolation and necrosis were evaluated semi-quantitatively. Briefly, the extent of tissue damages was graded from 0 to 4 according to the severity of, tubular dilatation, tubular vacuolation and tubular cell necrosis. The scoring system was as follows: $0=$ no change in the tubules; $1=<25 \%$ of tubular injury (mild); $2=25 \%$ to $50 \%$ of tubular involvement (moderate); $3=50 \%$ to $75 \%$ of tubules showing characteristic change (severe) and $4=$ more than $75 \%$ of tubular damage (very severe). Fifty fields were counted from each slide. All the assessments were done in a blinded fashion.

\section{Kidney weight-to-body weight ratio}

At the time of sacrifice the body weights and the kidney weights of rats were recorded. The kidney weight to body weight $(\mathrm{KW} / \mathrm{BW})$ ratio was calculated by simple arithmetic calculation of the kidney weight divided by body weight and then converted to percent.

\section{Statistical analysis}

All results are presented as Mean \pm S.E.M. Statistical significance was determined by one way analysis of variance (ANOVA) followed by Dunnett's test. In all cases $P<0.05$ was considered statistical significant.

\section{Results}

Effect of glycerol and quinacrine on blood urea nitrogen and serum creatinine

The BUN and Scr. the two principal clusters of renal function biomarkers were recorded in this study. There was a highly significant increase $(P<0.001)$ in serum BUN $(73.17 \pm 14.9 \mathrm{mg} / \mathrm{dL})$ in glycerol treated rats as compared to control group $(18.80 \pm 1.326 \mathrm{mg} / \mathrm{dL})$. The level of serum BUN following low $(46.1 \pm 10.7 \mathrm{mg} / \mathrm{dL}$, $P<0.05)$, medium $(38.1 \pm 3.5 \mathrm{mg} / \mathrm{dL}, P<0.05)$, and high $(33.0 \pm 0.7 \mathrm{mg} / \mathrm{dL}, P<0.01)$ dose treatment of quinacrine showed a significant attenuation of glycerol induced increase in BUN level (Fig. 1a).

Treatment of rats with glycerol also produced a significant increase $(P<0.01)$ in Scr. $(1.9 \pm 0.4 \mathrm{mg} / \mathrm{dL})$ as compared to control group $(0.83 \pm 0.024 \mathrm{mg} / \mathrm{dL})$ in $72 \mathrm{~h}$. The level of Scr. following low $(1.4 \pm 0.12 \mathrm{mg} / \mathrm{dL}, P<0.05)$, medium $(1.15 \pm 0.12 \mathrm{mg} / \mathrm{dL}, P<0.05)$, and high $(0.95 \pm$ $0.005 \mathrm{mg} / \mathrm{dL}, P<0.01)$ doses of quinacrine showed a dose dependent and significant attenuation of glycerol induced increase in Scr. levels (Fig. 1b).

\section{Effect of glycerol and quinacrine on serum electrolytes and phosphorus}

Acute kidney injury is associated with a significant electrolyte and acid-base disturbance. Even mild electrolyte disorders may be associated with highly significant morbidity and mortality. There was a significant $(P<0.01)$ increase in serum calcium $(9.7 \pm 0.16 \mathrm{mg} / \mathrm{dL})$ in glycerol treated rats as compared to control group $(9.02 \pm 0.123 \mathrm{mg} / \mathrm{dL})$. The serum level of calcium following treatment with low $(9.27 \pm 0.164 \mathrm{mg} / \mathrm{dL}, P<0.05)$, medium $(9.12 \pm 0.104$ $\mathrm{mg} / \mathrm{dL}, P<0.001)$, and high $(9.00 \pm 0.004 \mathrm{mg} / \mathrm{dL}, P<$ 0.001 ) doses of quinacrine showed a highly significant attenuation of glycerol induced increase in serum calcium level (Table 2).

Treatment of rats with glycerol produced a highly significant $(P<0.001)$ increase serum magnesium level $(3.23 \pm 0.237 \mathrm{mg} / \mathrm{dL})$ as compared to control rats $(1.76 \pm 0.111 \mathrm{mg} / \mathrm{dL})$. The serum magnesium levels following low $(2.45 \pm 0.206 \mathrm{mg} / \mathrm{dL}, P<0.05)$, medium 


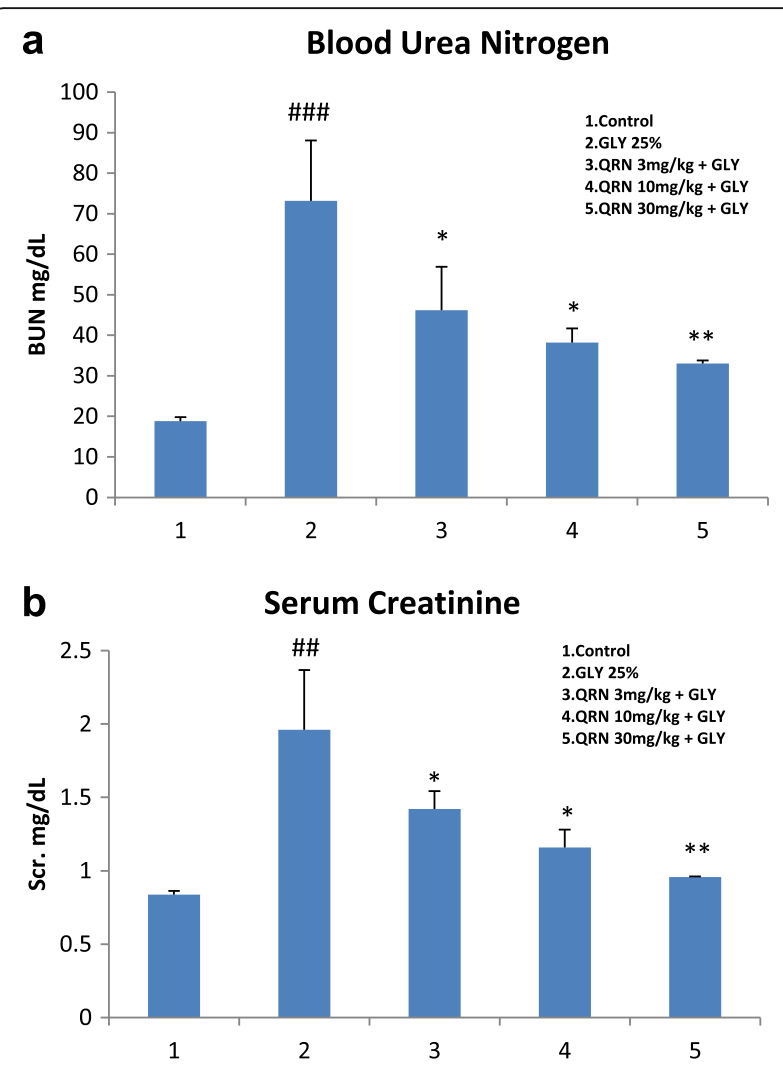

Fig. 1 Blood urea nitrogen and serum creatinine levels. a. The effect of quinacrine on glycerol induced changes in BUN. Glycerol produced a significant $(P<0.001)$ increase in BUN as compare to control group (\#\#\#). Treatment of rats with quinacrine in the doses of $3 \mathrm{mg} / \mathrm{kg}$ $(P<0.05), 10 \mathrm{mg} / \mathrm{kg}(P<0.05)$ and $30 \mathrm{mg} / \mathrm{kg}(P<0.01)$ significantly attenuated glycerol induced rise in BUN (* values compared to glycerol treated group). b. The effect of quinacrine on glycerol induced changes in Scr. Glycerol produced a significant $(P<0.01)$ increase in Scr. as compare to control group (\#\#). Treatment of rats with quinacrine in the doses of $3 \mathrm{mg} / \mathrm{kg}(P<0.05), 10 \mathrm{mg} / \mathrm{kg}(P<0.05)$ and $30 \mathrm{mg} / \mathrm{kg}(P<0.01)$ significantly attenuated glycerol induced rise in Scr. (* values compared to glycerol treated group)

$(2.33 \pm 0.155 \mathrm{mg} / \mathrm{dL}, P<0.01)$, and high $(2.03 \pm 0.113 \mathrm{mg} /$ $\mathrm{dL}, P<0.001)$ doses of quinacrine showed a highly significant reduction of glycerol induced increase in magnesium level (Table 2).

There was a decrease $(135 \pm 3.7 \mathrm{mmol} / \mathrm{L})$ in serum sodium level of glycerol treated rats as compared to rats in control $(140 \pm 4.4 \mathrm{mmol} / \mathrm{L})$ group. The glycerol induced decrease in sodium level was attenuated by low (136 \pm $4.0 \mathrm{mmol} / \mathrm{L})$, medium $(143 \pm 6.8 \mathrm{mmol} / \mathrm{L})$, and high (151 $\pm 5.6 \mathrm{mmol} / \mathrm{L} P<0.05$ ) doses of quinacrine (Table 2 ).

Glycerol treatment significant increased $(P<0.05)$ serum potassium level $(5.46 \pm 0.302 \mathrm{mmol} / \mathrm{L})$ as compared to control rats $(3.96 \pm 0.25 \mathrm{mmol} / \mathrm{L})$. The potassium levels in the rat treated with low $(5.15 \pm 0.302 \mathrm{mmol} / \mathrm{L})$, medium $(4.2 \pm 0.401 \mathrm{mmol} / \mathrm{L})$ and high $(3.85 \pm 0.241 \mathrm{mmol} / \mathrm{L}$, $P<0.01)$ doses of quinacrine showed a reversal of glycerol induced increase in potassium level (Table 2).

Glycerol produced a significant $(P<0.05)$ increase in serum phosphorus level $(7.53 \pm 0.588 \mathrm{mg} / \mathrm{dL})$ as compared to control group $(3.96 \pm 0.25 \mathrm{mg} / \mathrm{dL})$. The serum level of phosphorus in the rat treated with low $(6.68 \pm 0.706$ $\mathrm{mg} / \mathrm{dL})$, medium $(5.86 \pm 0.676 \mathrm{mg} / \mathrm{dL})$, and high $(4.8 \pm$ $0.311 \mathrm{mg} / \mathrm{dL}, P<0.001)$ doses of quinacrine showed a dose dependent attenuation of glycerol induced increase in serum phosphorus level (Table 2).

\section{Renal myeloperoxidase and malodialdehyde levels}

The neutrophil derived enzyme MPO is considered an important pathophysiogic factor in progression of renal disease. The tissue MPO activity was significantly $(P<0.05)$ higher $(1118.11 \pm 106.5 \mathrm{U} / \mathrm{min} / \mathrm{gm}$ tissue $)$ in glycerol treated rats as compared to control group $(673.8 \pm 77.7 \mathrm{U} / \mathrm{min} / \mathrm{gm}$ tissue). The MPO activity in the rat treated with low $(523.4 \pm 60.8 \mathrm{U} / \mathrm{min} / \mathrm{gm}$ tissue, $P<0.01)$, medium $(571.04 \pm 60.5 \mathrm{U} / \mathrm{min} / \mathrm{gm}$ tissue, $P<$ $0.001)$, and high $(623.75 \pm 30.5 \mathrm{U} / \mathrm{min} / \mathrm{gm}$ tissue, $P<$ 0.001 ) doses of quinacrine showed a significant attenuation of glycerol induced increase in MPO activity in kidney tissues (Fig. 2a).

Ischemia and chemical induced renal injury is associated with significant increase in MDA level. Treatment of rats with glycerol produced a significant $(P<0.05)$ increase in tissue MDA levels $(391.4 \pm 14.8 \mu \mathrm{mol})$ as compared to control rats $(251.5 \pm 12 \mu \mathrm{mol})$. The MDA level of rat kidney treated with low $(237.4 \pm 49.2 \mu \mathrm{mol}$, $P<0.05)$, medium $(254.7 \pm 34.4 \mu \mathrm{mol})$ and high $(181 \pm$ $30.1 \mu \mathrm{mol}, P<0.001)$ doses of quinacrine showed a significant attenuation of glycerol induced increase in MDA level in kidney tissues (Fig. 2b).

Table 2 Effect of quinacrine on glycerol-induced AKl; level of serum electrolytes and phosphorus

\begin{tabular}{|c|c|c|c|c|c|}
\hline Groups & Calcium mg/dL & Magnesium mg/dL & Sodium mmol/L & Potassium mmol/L & Phosphorus mg/dL \\
\hline Control & $9.21 \pm 0.123$ & $1.76 \pm 0.111$ & $140 \pm 4.4$ & $3.96 \pm 0.25$ & $5.98 \pm 0.119$ \\
\hline GLY 25\% & $9.73 \pm 0.164 \# \#$ & $3.23 \pm 0.237 \# \# \#$ & $135 \pm 3.7$ & $5.46 \pm 0.302 \#$ & $7.53 \pm 0.588 \#$ \\
\hline QRN 3 mg/kg + GLY & $9.27 \pm 0.164 *$ & $2.45 \pm 0.206^{*}$ & $136 \pm 4.0$ & $5.15 \pm 0.302$ & $6.68 \pm 0.706$ \\
\hline QRN $10 \mathrm{mg} / \mathrm{kg}+\mathrm{GLY}$ & $9.12 \pm 0.104^{* * *}$ & $2.33 \pm 0.155^{* *}$ & $143 \pm 6.8$ & $4.2 \pm 0.401$ & $5.86 \pm 0.676$ \\
\hline QRN $30 \mathrm{mg} / \mathrm{kg}+\mathrm{GLY}$ & $9.00 \pm 0.004^{* * *}$ & $2.03 \pm 0.113^{* * *}$ & $151 \pm 5.6^{*}$ & $3.85 \pm 0.241^{* *}$ & $4.8 \pm 0.311^{* * *}$ \\
\hline
\end{tabular}

Single intramuscular glycerol injection significantly increase the level of serum calcium, magnesium, potassium, phosphorus and lowered the level of sodium, whereas quinacrine treatment attenuate this alteration in serum electrolytes. Data expressed as mean $\pm \mathrm{SE}$. \# $P<0.05$, \#\# $P<0.01$ and \#\#\# $P<0.001$ as compare with control group. ${ }^{*} P<0.05,{ }^{* *} P<0.01$ and ${ }^{* * *} P<0.001$ as compare to glycerol treated group 


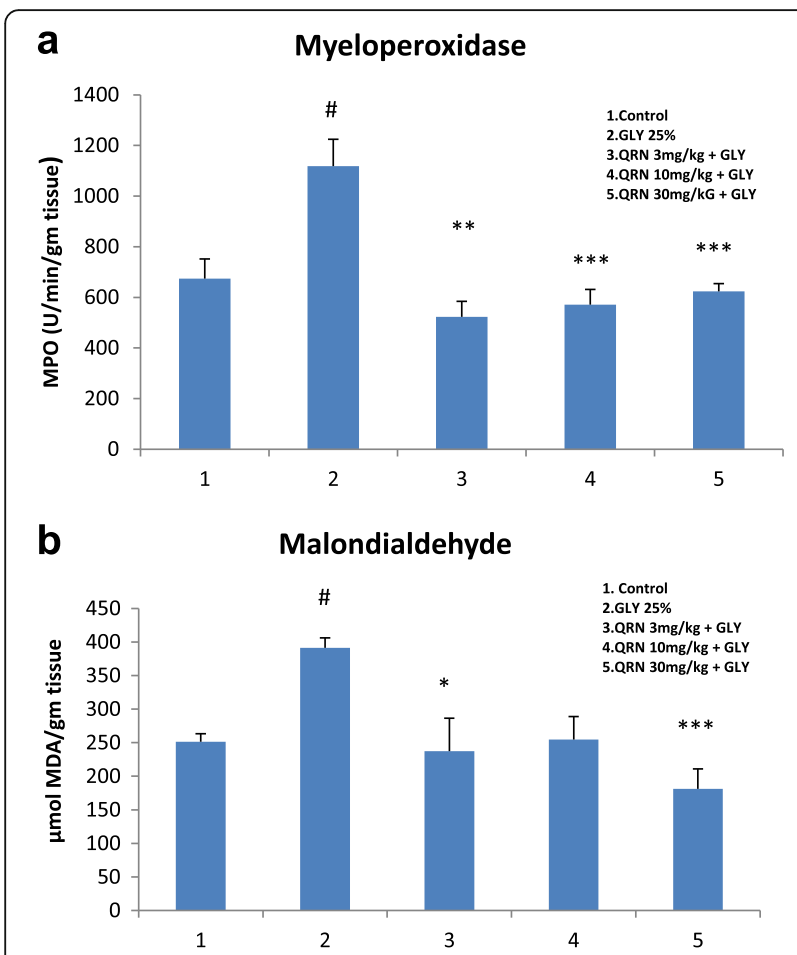

Fig. 2 Myeloperoxidase and malondialdehyde in kidney. a The effect of quinacrine on glycerol induced changes kidney MPO activity. Glycerol produced a significant $(P<0.01)$ increase in kidney MPO activity as compare to control group (\#). Treatment of rats with quinacrine in the doses of $3 \mathrm{mg} / \mathrm{kg}, 10 \mathrm{mg} / \mathrm{kg}(P<0.001)$ and $30 \mathrm{mg} / \mathrm{kg}(P<0.001)$ significantly attenuated glycerol induced rise in kidney MPO activity Scr. ( ${ }^{*}$ values compared to glycerol treated group). $\mathbf{b}$ The effect of quinacrine on glycerol induced changes kidney MDA level. Glycerol produced a significant $(P<0.01)$ increase in kidney MDA level as compare to control group (\#). Treatment of rats with quinacrine in the doses of $3 \mathrm{mg} / \mathrm{kg}(P<0.05)$, $10 \mathrm{mg} / \mathrm{kg}$ and $30 \mathrm{mg} / \mathrm{kg}(P<0.001)$ significantly attenuated glycerol induced rise in kidney MDA level. (* values compared to glycerol treated group)

\section{Kidney weight to body weight ratio}

There was a significant $(P<0.05)$ increase in KW $(1.481 \pm$ $0.041 \mathrm{gm})$ in glycerol treated rats as compared to control rats $(0.651 \pm 0.020 \mathrm{gm})$. The $\mathrm{KW}$ in the rats treated with low $(1.302 \pm 0.067 \mathrm{gm}, P<0.05)$, medium $(1.293 \pm 0.047$ gm, $P<0.01)$, and high $(1.017 \pm 0.059$ gm, $P<0.001)$ doses of quinacrine showed a significant attenuation of glycerol induced increase in KW (Table 3).

Similarly treatment of rats with glycerol produced a significant $(P<0.05)$ increase in KW/BW ratio $(0.755 \pm$ $0.031)$ as compared to control rats $(0.309 \pm 0.010)$. The $\mathrm{KW} / \mathrm{BW}$ ratio in low $(0.694 \pm 0.036)$, medium $(0.634 \pm$ $0.038, P<0.05)$, and high $(0.525 \pm 0.029, P<0.001)$ dose of quinacrine treated rats showed a significant attenuation of KW/BW ratio (Table 3 ).

\section{Histological findings}

The light microscopic findings of the kidneys of the treated rats are given in Table 4. The groups injected with glycerol showed widespread damage both in cortex and medullar region of the kidney. The microscopic changes include; the loss of microvilli, tubular dilatation and vacuolation, tubular necrotic lysis and cellular micro debris into the tubular lumen. Severe tubular damage were observed mainly in the distal end of the kidney, whereas inner medulla showed mainly tubular dilatation and cell debris.

Concomitant treatment with quinacrine significantly reversed glycerol induced histopathological changes in kidney (Fig. 3).

\section{Discussion}

The results of this study demonstrated that the treatment of animals with glycerol produced a significant increase in serum BUN and Scr (Fig. 1) suggesting the functional impairment of kidneys. Glycerol treatment also resulted in development of edema and enlargement of kidney which was evidence from increase in kidney weight/body weight ratio confirming a significant toxic insult to the renal tissue. Our histopathological studies showed significant structural changes, including tubular dilatation, vacuolation, necrosis and cellular debris in the kidneys of glycerol treated rats. Similar biochemical and histopathological changes have been reported earlier following glycerol treatment [32,33]. The treatment of rats with quinacrine dose dependently attenuated glycerol induced renal toxicity (Fig. 1 \& Table 4). Our earlier studies showed highly significant protective effect of

Table 3 Effect of quinacrine on glycerol induced body weight, kidney weight and kidney weight to body weight ratio

\begin{tabular}{lcll}
\hline & Body weight (gm) & Kidney weight (gm) & KW /BW ratio \\
\hline Control & $209.5 \pm 2.34$ & $0.651 \pm 0.020$ & $0.309 \pm 0.010$ \\
GLY 25\% & $196.8 \pm 3.28$ & $1.481 \pm 0.041 \#$ & $0.755 \pm 0.031 \#$ \\
QRN $3 \mathrm{mg} / \mathrm{kg}+\mathrm{GLY}$ & $193.6 \pm 3.17$ & $1.302 \pm 0.067^{*}$ & $0.694 \pm 0.036$ \\
QRN $10 \mathrm{mg} / \mathrm{kg}+\mathrm{GLY}$ & $195.5 \pm 2.86$ & $1.293 \pm 0.047^{* *}$ & $0.634 \pm 0.038^{*}$ \\
QRN $30 \mathrm{mg} / \mathrm{kg}+\mathrm{GLY}$ & $198.6 \pm 3.01$ & $1.017 \pm 0.059^{* * *}$ & $0.525 \pm 0.029^{* * *}$ \\
\hline
\end{tabular}

Effect of quinacrine on glycerol induced changes in kidney weight and body weight. The body weight was not change in all the treated groups but the kidney weight and KW/BW ratio significantly increased in glycerol treated groups. Quinacrine treatment showed a significant and dose dependent attenuation of glycerol induced increase in KW and KW/BW ratio. Data expressed as mean \pm SE. \# $P<0.001$ as compare with control group and ${ }^{*} P<0.05$, ${ }^{* *} P<0.01$ and ${ }^{* * *} P<0.001$ as compared with Glycerol treated group 
Table 4 Effect of Quinacrine on glycerol induced histopathological changes in kidney (higher scores indicate severe injury)

\begin{tabular}{llll}
\hline Groups & Tubular dilatation & Tubular voculation & Tubular necrosis \\
\hline Control & 0 & 0 & 0 \\
Glycerol25\% & $3.37 \pm 0.18 \# \# \#$ & $1.43 \pm 0.290 \#$ & $0.875 \pm 0.182 \# \#$ \\
QRN $3 \mathrm{mg} / \mathrm{kg}+\mathrm{GLY}$ & $2.50 \pm 0.25^{*}$ & $1.25 \pm 0.163$ & $0.812 \pm 0.209$ \\
QRN $10 \mathrm{mg} / \mathrm{kg}+\mathrm{GLY}$ & $1.87 \pm 0.27^{* *}$ & $0.81 \pm 0.209$ & $0.375 \pm 0.125^{*}$ \\
QRN $30 \mathrm{mg} / \mathrm{kg}+\mathrm{GLY}$ & $1.37 \pm 1^{* *}$ & $0.62 \pm 0.081^{*}$ & $0.125 \pm 0.125^{* *}$ \\
\hline
\end{tabular}

Effect of quinacrine on glycerol-induced AKI.. Glycerol treated rats developed significant histological changes in kidney tubules. Data expressed in mean \pm SE. $\# P<0.05$, \#\# $P<0.01$ and \#\#\# $P<0.001$ as compare to control group; ${ }^{*} P<0.05$, and ${ }^{* *} P<0.001$ as compare to glycerol treated group (G.3)

quinacrine against cyclosporine induced renal toxicity [34], ethanol induced gastric mucosal injury [35] and1-methyl4-phenyl-1,2,3,6-tetrahydropyridine (MPTP) induced neuronal injury [36]. Quinacrine has also been shown to exert significant protective effect against ischemia induced myocardial [37] and cerebral [38, 39] injury.

Alteration of phospholipid metabolism during the renal ischemic injury is well documented [23, 40]. Glycerol induced ischemic insult results in derangement of cellular phospholipid membrane of renal tissue [12, 41]. PLA2 enzymes catalyze the hydrolysis of the 2-acyl bond of 3-nphosphoglycerides, resulting in release of fatty acid from the second carbon group of glycerol. This enzyme specifically recognizes the sn- 2 acyl bond of phospholipids and catalytically hydrolyzes the bond releasing arachidonic acid (AA) and lysophospholipids [42]. Free AA is the precursor of the vasoactive eicosanoids including prostaglandins [43]. Treatment with glycerol is known to significantly disturb the equilibrium between the AA metabolites including vasodilator prostacyclin (PGI2) and vasoconstrictor thromboxane (TxA2) in favor of TxA2 causing impairment of renal blood flow resulting in ischemic injury [44-46]. Quinacrine, a widely used inhibitor of lipolytic enzyme PLA2 has been shown to dose-dependently inhibit lipolytic release of arachidonate and generation of eicosanoids from kidney medulla [47-49]. Besides being a non-selective PLA2 inhibitor quinacrine has also been shown to possess significant cyclooxygenase inhibitory activity [50]. Thus the attenuation of glycerol induced renal injury by quinacrine may be attributed to inhibition of PLA2 induced lipolytic activity and restoration of physiological balance of the vasoactive eicosanoids in renal tissue resulting in stabilization of cell membrane.

The mechanism of glycerol induced renal injury is not entirely clear, a host of inflammatory mediators and cell mediated immune responses are believed to be involved in pathophysiology of AKI [12, 51]. We observed a significant increase in neutrophil-derived enzyme, MPO in the kidney of glycerol treated rats (Fig. 2) suggesting a robust neutrophil activity in the tissue [52]. Bolisetty and Agarwal [53] showed that neutrophil accumulate in kidney following ischemic insult due to their transmigration into the interstitium. Alteration of epithelial and endothelial cell integrity by neutrophils leads to kidney injury. Takasaki et al. [54] suggested that neutrophil cause kidney damage through the excessive release of oxygen radicals and proteases. In this study we observed a significant attenuation of MPO activity in the kidney tissue of quinacrine treated rats (Fig. 2). The exact mechanism by which quinacrine may reverse neutrophil mediated renal injury is not fully understood. Daniel et al. [55] reported a significant inhibition of neutrophil mediated superoxide generation and AA release by quinacrine. Earlier, anti-PLA2 antibodies have been shown to significantly suppress the neutrophil activity [56]. Beside affecting innate and adaptive immunity neutrophils are well recognized as one of the major player during inflammatory damage to the tissues [57]. Korrapati et al. [29] reported a significant increase in kidney NF-kB at 24 to $48 \mathrm{~h}$ after glycerol administration in rats. The available data clearly suggest that NF-kB and the major tumor suppressor P53 work in tandem in the pathogenesis of AKI [58, 59]. While NF-kB is a potent inflammatory mediator and plays a major role in the synthesis of pro-inflammatory cytokines and chemokines [60], the anti-inflammatory effect of P53 seems to be universal [59]. P53 has been shown to mitigate inflammation and exerts nephroprotective effect by several earlier investigators [61, 62]. Quinacrine and its derivatives have been shown to suppress NF-kB and increased P53 protein by causing chromatin trapping of the FACT (facilitates chromatin transcription) complex [63, 64]. Moreover quinacrine has been shown to inhibit histamine methyltransferase, a major enzyme responsible for catabolizing histamine, resulting in increased histamine level in kidney and other tissues [65]. Histamine participates in regulation of wide variety of pathophysiological events including vasomotor actively and inflammatory responses. Histamine infusion directly in renal artery decreases renal vascular resistance and increased blood flow through its action on $\mathrm{H} 1$ and $\mathrm{H} 2$ receptors [66]. Histamine through $\mathrm{H} 1$ receptors augment inflammatory responses [67]; whereas through $\mathrm{H} 2$ receptors it suppress inflammation by reducing inflammatory cytokines and chemokines $[68,69]$. The ability of quinacrine to activate P53 and to inhibit NF-kB and histamine methyltrasferase may contribute to its nephroprotective activity $[70,71]$. 

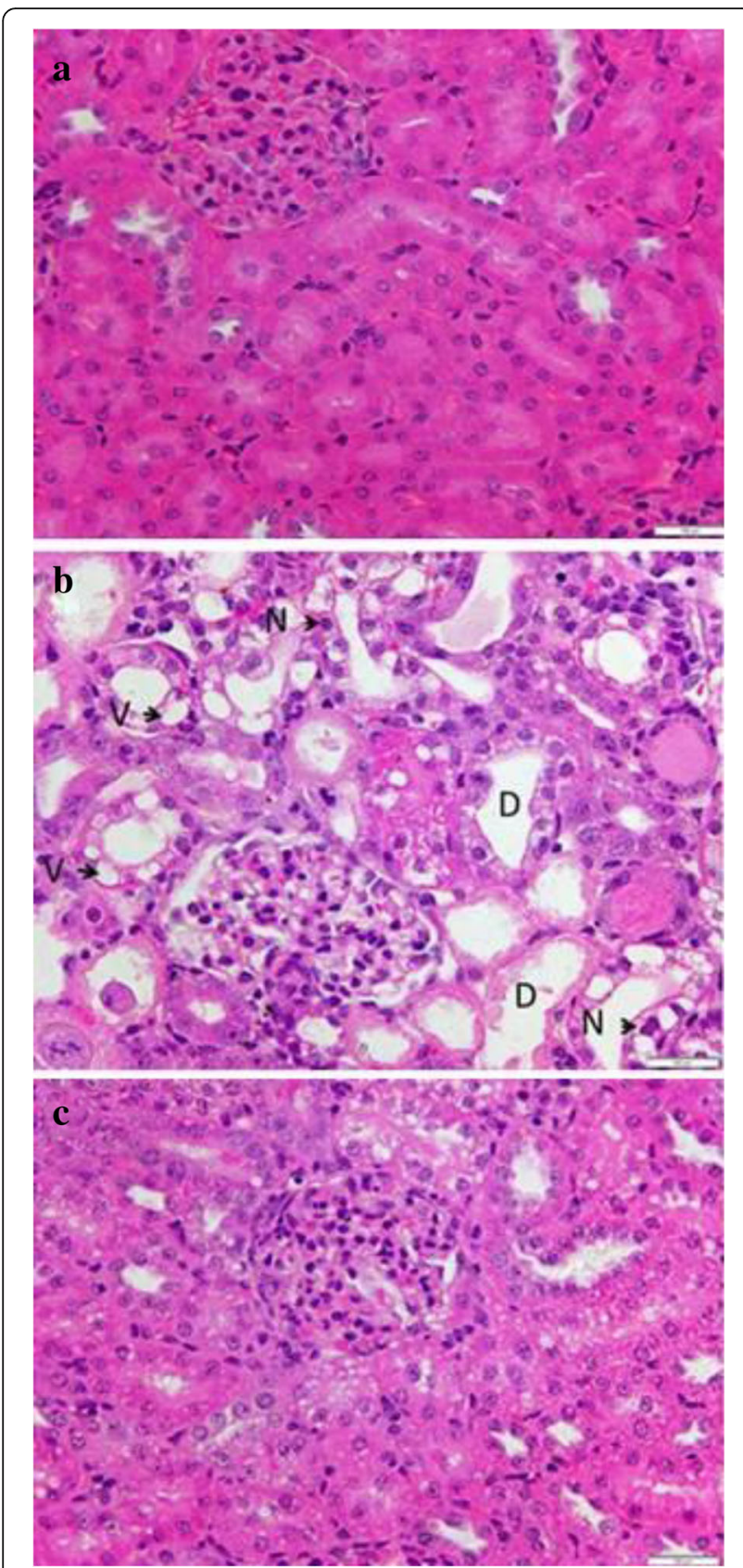

Fig. 3 Histological appearance of kidney in control and treated rat. Representative renal histopathology using hematoxylin and eosin staining of sections presented with magnification $\times 200$. a Kidney section of control group, $\mathbf{b}$ Kidney section of glycerol treated group, c Kidney section of quinacrine and glycerol treated group. Microscopic changes include tubular dilatation (D), vacuolation $(V)$ and necrosis $(N)$

The result of this study showed a significant increase in kidney MDA levels of the rats treated with glycerol (Fig. 2). Malondialdehyde is a highly reactive molecule and one of the most reliable marker of oxidative stress. Glycerol-induced AKI has been shown to increase the generation of reactive oxygen species (ROS) and/or depletion of antioxidant defense system [64]. Kidney is an organ highly vulnerable to oxidative stress induced tissue injury, likely due to the abundance of long-chain polyunsaturated fatty acids in the composition of renal lipids [72]. Treatment of the rats with quinacrine significantly attenuated glycerol induced increase in kidney MDA levels (Fig. 2). Turnbull et al. [73] showed highly significant antioxidant activity of quinacrine. Inhibition of MDA production by quinacrine has been attributed to its ability to protect unsaturated fatty acids from lipid peroxidation by binding to membrane phospholipids [74]. Moreover Fujmoto et al. [75] suggested that lipid peroxidation is closely associated with prostaglandin generating system in kidney, especially at the AA (substrate) and cyclic endoperoxide level during the synthesis of prostaglandins. Quinacrine might decrease the production of MDA from endoperoxides by inhibiting the release of AA which is generated by phospholipid cell membrane under the influence of phospholipase enzymes. Besides inhibiting the oxidative stress and PLA2 activity, the nephroprotective effect of quinacrine may partly be attributed to the improvement of microcirculation as a result of its direct vasodilator activity $[76,77]$.

Treatment of rats with glycerol produced a significant increase in serum $\mathrm{Ca} 2+$ levels, whereas quinacrine dose dependently attenuated glycerol induced hypercalcemia (Table 2). Our findings support the earlier investigators who also observed high serum $\mathrm{Ca} 2+$ levels in glycerol treated rats $[78,79]$. A key role of $\mathrm{Ca} 2+$ in cell injury has long been recognized. The lethal cell injury develops in a tissue due to mitochondrial accumulation and sequestration $\mathrm{Ca} 2+$. The major mechanisms by which $\mathrm{Ca} 2+$ promotes cell injury include activation of phospholipases, endonucleases, proteases and protein kinases direct and indirect effects on mitochondrial membrane permeabil and effects on contractile and cytoskeletal structures and functions [80]. Although our study is limited due to absence of tissue $\mathrm{Ca} 2+$ levels, a significant increase serum $\mathrm{Ca} 2+$ observed in this study (Table 2.) may be attributed to hypovolemia, metabolic acidosis [81] and compromised tubular fluid dynamics resulting in electrolyte imbalance following glycerol administration [82]. Reversal of toxin induced alteration in $\mathrm{Ca} 2+$ with a variety of agents has been beneficial in ameliorating the degree of cell injury in a number of experimental settings [83, 84].

In contrast to hypercalcemia, we observed a decrease in serum sodium $(\mathrm{Na}+)$ in glycerol treated rats. Our findings are in agreement with earlier investigators who reported a significant decrease in serum $\mathrm{Na}+$ in glycerol induced rhabdomyolysis in rats $[85,86]$. The important role of $\mathrm{Na}+$ in the pathogenesis of glycerol induced renal injury is evident from the findings of numerous earlier studies. Infusion of $\mathrm{Na}+(150 \mathrm{mmol} / \mathrm{L})$ protected animal against glycerol induced renal injury [87], whereas sodium 
restriction has been shown to aggravate glycerol induced acute renal failure [88]. Park et al. [72] showed that glycerol induced renal failure in rats was associated with significant increase in fractional excretion of sodium. Treatment of rats with quinacrine attenuated glycerol induced change in $\mathrm{Na}+$ and $\mathrm{Ca} 2+$ levels (Table 2). Glycerol induced kidney injury is associated with ischemic insult to renal tissue resulting in activation of PLA2 enzymes [89]. Phospholipase A2 and its metabolic products inducing AA and prostaglandins have been implicated in regulation of ion trafficking through the cell membranes [90]. Besides reversing PLA2 induced alteration of ion channels quinacrine has been shown to directly modulate ion channels in a selective manner [91, 92]. The result of this study clearly suggest that restoration of ion homeostasis may help in preventing renal injury.

There are some limitation in this study, we used serum creatinine and blood urea nitrogen as the biochemical marker of renal function, which were supported by our histopathological studies of kidney tissue. However urine analysis based studies including urine volume, urine creatinine and creatinine clearance tests could have strengthen our claims of attenuation of glycerol induced renal impairment by quinacrine. Moreover our claim that nephroprotective effect of quinacrine may be attributed to its universally known PLA2 inhibiting activity could have been further substantiated by measuring PLA2 activity and arachidonic acid metabolites in kidney tissue. Further studies are warranted to gain more insight in the mechanism of nephroprotective action of quinacrine.

\section{Conclusion}

In conclusion, the result of this study suggest a significant role of oxidative stress, proinflammatory myeloperoxidase and electrolyte imbalance in the pathogenesis of glycerol induced renal injury. Treatment of rats with quinacrine produced a highly significant and dose dependent nephroprotection against glycerol induced renal injury. The ability of quinacrine to mitigate oxidative stress suppress inflammatory mediators and to maintain electrolyte hemostasis makes it potential candidate for therapeutic exploitation for the treatment of drug/chemical induced renal injury.

\footnotetext{
Abbreviations

AA: Arachidonic acid; AKI: Acute kidney injury; ANOVA: One way analysis of variance; BUN: Blood urea nitrogen; BW: Body weight; Ca2+: Calcium; KW: Kidney weight; MDA: Malondialdehyde; MPO: Myeloperoxidase; Na +: Sodium; PG12: Prostacyclin; PLA2: Phospholipase; ROS: Reactive oxygen species; Scr: Serum creatinine; TBARS: Thiobarbituricacid reactive substances; TxA2: Thromboxane A2
}

\section{Acknowledgements}

This work was supported by the Prince Sultan Military Medical City, Riyadh, Saudi Arabia. Author would like to thank Dhayasankar Sigamani for the help in histopathology section preparation and photography.
Funding

Not applicable.

\section{Availability of data and materials}

All data related to this study are available in the Research Center, Prince Sultan Military Medical City, Riyadh, Saudi Arabia and can provided upon request.

\section{Authors' contributions}

All the authors participated in the design of the study, the interpretation and analysis of the data and the review of the manuscript. AA, DY and MT conducted the experiment and analyzed the data. AA, DY and MT wrote the manuscript. KA and AD gave constructive suggestions during the preparation of the manuscript. All the authors read and approved the final manuscript. All the authors also participated in revision of the manuscript.

\section{Competing interests}

The authors declare that they have no competing interests.

\section{Consent for publication}

Not applicable.

\section{Ethics approval}

The experiment was performed in a humane manner in accordance with Ethical Guidelines for Care and Use of Laboratory Animals of Prince Sultan Military Medical City, Riyadh, Saudi Arabia. This study was approved by the Research and Ethical Committee of Prince Sultan Military Medical City,

Riyadh, Saudi Arabia (approval reference number 27/2015).

\section{Author details}

${ }^{1}$ Scientific Research Centre, Prince Sultan Military Medical City, Riyadh, Saudi Arabia. ${ }^{2}$ Department of Urology, Prince Sultan Military Medical City, Riyadh, Saudi Arabia.

Received: 11 November 2015 Accepted: 13 January 2017

Published online: 28 January 2017

\section{References}

1. Liaño F, Pascual J. Epidemiology of acute renal failure: a prospective, multicenter, community-based study. Madrid Acute Renal Failure Study Group. Kidney Int. 1996;50(3):811-8.

2. Wilson DR, Thiel G, Arce ML, Oken DE. Glycerol induced hemoglobinuric acute renal failure in the rat. 3. Micropuncture study of the effects of mannitol and isotonic saline on individual nephron function. Arce Nephron. 1967:4(6):337-55.

3. Abul-Ezz SR, Walker PD, Shah SV. Role of glutathione in an animal model of myoglobinuric acute renal failure. Proc Natl Acad Sci U S A. 1991;88(21):9833-7.

4. Chander V, Chopra K. Molsidomine a nitric oxide donor and L-arginine protects against rhabdomyolysis-induced myoglobinuric acute renal failure. Biochim Biophys Acta. 2005;1723(1-3):208-14.

5. Malik GH. Rhabdomyolysis and myoglobin-induced acute renal failure. Saudi J Kidney Dis Transpl. 1998;9(3):273-84.

6. Efstratiadis G, Voulgaridou A, Nikiforou D, Kyventidis A, Kourkouni E, Vergoulas G. Rhabdomyolysis updated. Hippokratia. 2007;11(3):129-37.

7. Hsu CH, Kurtz TW, Waldinger TP. Cardiac output and renal blood flow in glycerol-induced acute renal failure in the rat. Circ Res. 1977;40(2):178-82.

8. Zager RA, Burkhart KM, Conrad DS, Gmur DJ, Zager RA. Rhabdomyolysis and myohemoglobinuric acute renal failure. Kidney Int. 1996;49(2):314-26.

9. Zager RA, Burkhart KM, Conrad DS, Gmur DJ. Iron, hemeoxygenase, and glutathione: effects on myohemoglobinuric proximal tubular injury. Kidney Int. 1995;48(5):1624-34

10. Zager RA, Burkhart KM. Differential effects of glutathione and cysteine on $\mathrm{Fe} 2+, \mathrm{Fe} 3+, \mathrm{H} 2 \mathrm{O} 2$ and myoglobin-induced proximal tubular cell attack. Kidney Int. 1998;53(6):1661-72.

11. Moore KP, et al. A causative role for redox cycling of myoglobin and its inhibition by alkalinization in the pathogenesis and treatment of rhabdomyolysis-induced renal failure. J Biol Chem. 1998;273(48):31731-7.

12. Homsi E, Janino P, de Faria JB. Role of caspases on cell death, inflammation, and cell cycle in glycerol-induced acute renal failure. Kidney Int. 2006; 69(8):1385-92. 
13. Zager RA, Sacks BM, Burkhart KM, Williams AC. Plasma membrane phospholipid integrity and orientation during hypoxic and toxic proximal tubular attack. Kidney Int. 1999;56(1):104-17.

14. Farber JL, Chien KR, Mittnacht Jr S. Myocardial ischemia: the pathogenesis of irreversible cell injury in ischemia. Am J Pathol. 1981;102(2):271-81.

15. Humes HD, Jackson NM, O'Connor RP, Hunt DA, White MD. Pathogenetic mechanisms of nephrotoxicity: insights into cyclosporine nephrotoxicity. Transplant Proc. 1985;17(4 Suppl 1):51-62.

16. Singer SJ, Nicolson GL. The fluid mosaic model of the structure of cell membranes. Science. 1972;175(4023):720-31.

17. Rubalcava B, Rodbell M. The role of acidic phospholipids in glucagon action on rat liver adenylate cyclase. J Biol Chem. 1973;248(11):3831-7.

18. Dahl JL, Hokin LE. The sodium-potassium adenosine-triphosphatase. Annu Rev Biochem. 1974:43:327-55.

19. Cullis PR, deKruiiff B, Hope MJ, Nayar R. Phospholipids and membrane transport. Can J Biochem. 1980;58:1091-100.

20. Green DE, Fry M, Blondin GA. Phospholipids as the molecular instruments of ion and solute transport in biological membranes. Proc Natl Acad Sci U S A. 1980;77(1):257-61.

21. Chien KR, Abrams J, Serroni A, Martin JT, Farber JL. Accelerated phospholipid degradation and associated membrane dysfunction in irreversible, ischemic liver cell injury. J Biol Chem. 1978;253(13):4809-17.

22. Chien KR, Reeves JP, Buja LM, Bonte F, Parkey RW, Willerson JT. Phospholipid alterations in canine ischemic myocardium. Temporal and topographical correlations with Tc-99 m-PPi accumulation and an in vitro sarcolemmal Ca +2 permeability defect. Circ Res. 1981;48(5):711-9.

23. Matthys E, Patel Y, Kreisberg J, Stewart JH, Venkatachalam M. Lipid alterations induced by renal ischemia: pathogenic factor in membrane damage. Kidney Int. 1984;26(2):153-61.

24. Lee JC, Simonyi A, Sun AY, Sun GY. Phospholipases A2 and neural membrane dynami cs: implications for Alzheimer's disease. J Neurochem. 2011;116(5):813-9.

25. Irvine RF. How is the level of free arachidonic acid controlled in mammalian cells? Biochem J. 1982;204(1):3-16.

26. Dennis EA, Rhee SG, Billah MM, Hannun YA. Role of phospholipase in generating lipid second messengers in signal transduction. FASEB J. 1991;5(7):2068-77.

27. Vigo C, Lewis GP, Piper PJ. Mechanisms of inhibition of phospholipase A2. Biochem Pharmacol. 1980;29(4):623-7.

28. Korrapati MC, Shaner BE, Schnellmann RG. Recovery from glycerol-induced acute kidney injury is accelerated by suramin. J Pharmacol Exp Ther. 2012;341(1):126-36

29. Charan J, Kantharia ND. How to calculate sample size in animal studies? J Pharmacol Pharmacother. 2013;4(4):303-6.

30. Barone FC, Hillegass LM, Price WJ, White RF, Lee EV, Feuerstein GZ, Sarau HM, Clark RK, Griswold DE. Polymorphonuclear leukocyte infiltration into cerebral focal ischemic tissue: myeloperoxidase activity assay and histologic verification. J Neurosci Res. 1991;29(3):336-45.

31. Ohkawa H, Ohishi N, Yagi K. Assay for lipid peroxides in animal tissues by thiobarbituric acid reaction. Anal Biochem. 1979:95(2):351-8.

32. Ustundag S, Sen S, Yalcin O, Ciftci S, Demirkan B, Ture M. L-Carnitine ameliorates glycerol-induced myoglobinuric acute renal failure in rats. Ren Fail. 2009;31(2):124-33.

33. Bowmer CJ, Collis MG, Yates MS. Effect of the adenosine antagonist 8 phenyltheophylline on glycerol-induced acute renal failure in the rat. Br J Pharmacol. 1986;88(1):205-12

34. Al Khader A, al Sulaiman M, Kishore PN, Morais C, Tariq M. Quinacrine attenuates cyclosporine-induced nephrotoxicity in rats. Transplantation. 1996;62(4):427-35

35. Al Moutaery AR, Tariq M. Effect of quinacrine, a phospholipase A2 inhibitor on stress and chemically induced gastroduodenal ulcers. Digestion. 1997;58(2):129-37.

36. Tariq M, Khan HA, Al Moutaery K, Al DS. Protective effect of quinacrine on striatal dopamine levels in 6-OHDA and MPTP models of Parkinsonism in rodents. Brain Res Bull. 2001;54(1):77-82.

37. Chiariello M, Ambrosio G, Cappelli-Bigazzi M, Nevola E, Perrone-Filardi P, Marone $\mathrm{G}$, Condorelli M. Inhibition of ischemia-induced phospholipase activation by quinacrine protects jeopardized myocardium in rats with coronary artery occlusion. J Pharmacol Exp Ther. 1987;241(2):560-8.

38. Phillis JW. Cerebroprotective action of the phospholipase inhibitor quinacrine in the ischemia/reperfused gerbil hippocampus. Life Sci. 1996;58(6):L97-101.
39. Estevez AY, Phillis J. The phospholipase A2 inhibitor, quinacrine, reduces infarct size in rats after transient middle cerebral artery occlusion. Brain Res. 1997;752(1-2):203-8

40. Weinberg JM. The cell biology of ischemic renal injury. Kidney Int. 1991; 39(3):476-500

41. Duan SB, Liu FY, Luo JA, Wu HW, Liu RH, Peng YM, Yang XL. Nephrotoxicity of high- and low-osmolar contrast media. The protective role of amlodipine in a rat model. Acta Radiol. 2000;41(5):503-7.

42. Dennis EA. Diversity of group types, regulation, and function of phospholipase A2. J Biol Chem. 1994;269(18):13057-60.

43. Balsinde J, Winstead MV, Dennis EA. Phospholipase A(2) regulation of arachidonic acid mobilization. FEBS Lett. 2002;531(1):2-6.

44. Watson AJ, Stout RL, Adkinson Jr NF, Solez K, Whelton A. Selective inhibition of thromboxane synthesis in glycerol-induced acute renal failure. Am J Kidney Dis. 1986;8(1):26-30.

45. Hatziantoniou C, Papanikolaou N. Renal effects of the inhibitor of thromboxane A2-synthetase OKY-046. Experientia. 1986:42(6):613-5.

46. Xu N. Effect of electroacupuncture at "taixi" point on plasma thromboxane A2 and prostacyclin in the rabbit with renal ischemia. Zhen Ci Yan Jiu. 1993;18(3):240-2

47. Gao JT, Liu SH, Yan YE, Wu Y, Wu HT, Xing C, Ge XM, Wang H, Zhao YQ, Fan M. Quinacrine protects neuronal cells against heat-induced injury. Cell Biol Int. 2009:33(8):874-81.

48. Erman A, Azuri R, Raz A. Prostaglandin biosynthesis in rabbit kidney: mepacrine inhibits renomedullary cyclooxygenase. Biochem Pharmacol. 1984;33(1):79-82

49. Limas C, Limas CJ. Enhanced renomedullary prostaglandin synthesis in spontaneously hypertensive rats: role of a phospholipase A2. Am J Physiol. 1979;236(1):H65-72.

50. Raz A. Mepacrine blockade of arachidonate-induced washed platelet aggregation: relationship to mepacrine inhibition of platelet cyclooxygenase. Thromb Haemost. 1983;50(4):784-6.

51. Bank N, Aynedjian HS. Role of thromboxane in impaired renal vasodilatation response to acetylcholine in hypercholesterolemic rats. J Clin Invest. 1992;89(5):1636-42

52. Akcay A, Nguyen Q, Edelstein CL. Mediators of inflammation in acute kidney injury. Mediators Inflamm. 2009;2009:137072. Epub 2010 Feb 21.

53. Deng $L L$, Zhong $L$, Lei JR, Tang L, Liu L, Xie SQ, Liao XH. Protective effect of lipoxin A4 against rhabdomyolysis-induced acute kidney injury in rats. Xi Bao Yu Fen ZiMian Yi XueZaZhi. 2012;28(9):907-10.

54. Bolisetty $S$, Agarwal A. Neutrophils in acute kidney injury: not neutral any more. Kidney Int. 2009;75(7):674-6.

55. Takasaki J, Kawauchi Y, Urasaki T, Tanaka H, Usuda S, Masuho Y. Antibodies against type II phospholipase A2 prevent renal injury due to ischemia and reperfusion in rats. FEBS Lett. 1998;440(3):377-81.

56. Daniels I, Lindsay MA, Keany Cl, Burden RP, Fletcher J, Haynes AP. Role of arachidonic acid and its metabolites in the priming of NADPH oxidase in human polymorphonuclear leukocytes by peritoneal dialysis effluent. Clin Diagn Lab Immunol. 1998:5(5):683-9.

57. Kramer RM, Hession C, Johansen B, Hayes G, McGray P, Chow EP, Tizard R, Pepinsky RB. Structure and properties of a human non-pancreatic phospholipase A2. J Biol Chem. 1989;264(10):5768-75.

58. Mayadas TN, Cullere $X$, Lowell CA. The multifaceted functions of neutrophils, Annu Rev Pathol. 2014;9:181-218.

59. Gudkov AV, Gurova KV, Komarova EA. Inflammation and p53: a tale of two stresses. Genes Cancer. 2011;2(4):503-16.

60. Dagher PC, Mai EM, Hato T, Lee SY, Anderson MD, Karozos SC, Mang HE, Knipe NL, Plotkin Z, Sutton TA. The p53 inhibitor pifithrin-a can stimulate fibrosis in a rat model of ischemic acute kidney injury. Am J Physiol Ren Physiol. 2012;302(2):F284-91.

61. Brubaker SW, Bonham KS, Zanoni I, Kagan JC. Innate immune pattern recognition: a cell biological perspective. Annu Rev Immunol. 2015;33:257-90.

62. Komarova EA, Krivokrysenko V, Wang K, Neznanov N, Chernov MV, Komarov PG, Brennan ML, Golovkina TV, Rokhlin OW, Kuprash DV, Nedospasov SA, Hazen SL, Feinstein $E$, Gudkov AV. p53 is a suppressor of inflammatory response in mice. FASEB J. 2005;19(8):1030-2.

63. Liu B, Chen Y, St Clair DK. ROS and p53: a versatile partnership. Free Radic Biol Med. 2008:44(8):1529-35.

64. Gasparian AV, Burkhart CA, Purmal AA, Brodsky L, Pal M, Saranadasa M, Bosykh DA, Commane M, Guryanova OA, Pal S, Safina A, Sviridov S, Koman IE, Veith J, Komar AA, Gudkov AV, Gurova KV. Curaxins: anticancer 
compounds that simultaneously suppress NF-kB and activate p53 by targeting FACT. Sci Transl Med. 2011;3(95):95ra74.

65. Dermawan JK, Gurova K, Pink J, Dowlati A, De S, Narla G, Sharma N, Stark GR. Quinacrine overcomes resistance to erlotinib by inhibiting FACT, NF-KB, and cell-cycle progression in non-small cell lung cancer. Mol Cancer Ther. 2014;13(9):2203-14.

66. Horton JR, Sawada K, Nishibori M, Zhang X, Cheng X. Two polymorphic forms of human histamine methyltransferase: structural, thermal, and kinetic comparisons. Structure. 2001;9(9):837-49.

67. Radke KJ, Selkurt EE, Willis LR. The role of histamine $\mathrm{H} 1$ and $\mathrm{H} 2$ receptors in the canine kidney. Ren Physiol. 1985;8(2):100-11.

68. Jutel M, Blaser K, Akdis CA. Histamine in allergic inflammation and immune modulation. Int Arch Allergy Immunol. 2005;137(1):82-92. Epub 2005 Apr 12.

69. Hiraga N, Adachi N, Liu K, Nagaro T, Arai T. Suppression of inflammatory cell recruitment by histamine receptor stimulation in ischemic rat brains. Eur J Pharmacol. 2007;557(2-3):236-44. Epub 2006 Nov 14.

70. Akdis CA, Simons FE. Histamine receptors are hot in immunopharmacology. Eur J Pharmacol. 2006;533(1-3):69-76. Epub 2006 Jan 31.

71. Gurova KV, Hill JE, Guo C, Prokvolit A, Burdelya LG, Samoylova E, Khodyakova AV Ganapathi R, Ganapathi M, Tararova ND, Bosykh D, Lvovskiy D, Webb TR, Stark GR, Gudkov AV. Small molecules that reactivate p53 in renal cell carcinoma reveal a NF-kappaB-dependent mechanism of p53 suppression in tumors. Proc Natl Acad Sci U S A. 2005;102(48):17448-53.

72. Park CH, Tanaka T, Cho EJ, Park JC, Shibahara N, Yokozawa T. Glycerol-induced renal damage improved by 7-O-galloyl-D-sedoheptulose treatment through attenuating oxidative stress. Biol Pharm Bull. 2012;35(1):34-41.

73. Ozbek E. Induction of oxidative stress in kidney. Int J Nephrol. 2012;2012: 465897.

74. Turnbull S, Tabner BJ, Brown DR, Allsop D. Quinacrine acts as an antioxidant and reduces the toxicity of the prion peptide PrP106-126. Neuroreport. 2003;14(13):1743-5.

75. Nagai J, Tanaka M, Hibasami H, Ikeda T. Inhibition of oxidative hemolysis and lipid peroxidation by mepacrine. J Biochem. 1981;89(4):1143-8.

76. Fujimoto $Y$, Tanioka H, Keshi I, Fujita T. The interaction between lipid peroxidation and prostaglandin synthesis in rabbit kidney-medulla slices. Biochem J. 1983;212(1):167-71.

77. Shayevitz JR, McShane AJ, Traystman RJ, Gurtner GH. Mepacrine attenuates pulmonary vasoreactivity in rabbits. J Appl Physiol (1985). 1989;66(4):1921-6.

78. McAnulty JF, Huang XQ. The effects of administering quinacrine during ultraprofound hypothermia on warm ischemic kidney cortex tissue. J Pharmacol Exp Ther. 1996;277(2):691-9.

79. Al-Otaibi KE, Al Elaiwi AM, Tariq M, Al-Asmari AK. Simvastatin attenuates contrast-induced nephropathy through modulation of oxidative stress, proinflammatory myeloperoxidase, and nitric oxide. Oxid Med Cell Longev. 2012;2012:831748. doi:10.1155/2012/831748. Epub 2012 Oct 10.

80. Ayvaz S, Aksu B, Kanter M, Uzun H, Erboga M, Colak A, Basaran UN, Pul M Preventive effects of hyperbaric oxygen treatment on glycerol-induced myoglobinuric acute renal failure in rats. J Mol Histol. 2012;43(2):161-70. doi:10.1007/s10735-012-9391-5. Epub 2012 Feb 7.

81. Humes HD. Role of calcium in pathogenesis of acute renal failure. Am J Physiol. 1986;250(4 Pt 2):F579-89.

82. Razzak AA, Mousah HA, Althamir SN. Nifedipine, calcium channel blocker against glycerol-induced acute renal failure in rats. Kufa Med J. 2004;7(1):14.

83. Singh AP, Singh AJ, Singh N. Pharmacological investigations of Punica granatum in glycerol-induced acute renal failure in rats. Indian J Pharm. 2011;43(5):551-6. doi:10.4103/0253-7613.84971.

84. Salahudeen AK, Wang C, Bigler SA, Dai Z, Tachikawa H. Synergistic renal protection by combining alkaline-diuresis with lipid peroxidation inhibitors in rhabdomyolysis: possible interaction between oxidant and non-oxidant mechanisms. Nephrol Dial Transplant. 1996;11:635-42.

85. Najafzadeh H, Razijalali M, Morovvati H, Navvabi L. Evaluation the effect of cimetidine, estradiol and vitamin $\mathrm{E}$ on myoglobinuric renal toxicity in rats. Am Eurasian J Toxicol Sci. 2011;3(3):177-83.

86. Kaya O, Aydogdu N, Tastekin E, Karadag CH, Unduz OG, Sut N. Effects of losartan on glycerol-induced myoglobinuric acute renal failure in rats. Kafkas Univ Vet Fak Derg. 2013;19(2):253-8. doi:10.9775/kvfd.2012.7620.

87. Papanicolaou N, Callard P, Bariety J, Milliez P. The effect of indomethacin and prostaglandin (PGE2) on renal failure due to glycerol in saline-loaded rats. Clin Sci Mol Med. 1975;49(5):507-10.
88. Abdulkader RC, Yuki MM, Paiva AC, Marcondes M. Prolonged inhibition of angiotensin II attenuates glycerol-induced acute renal failure. Braz J Med Biol Res. 1988;21(2):233-9.

89. Nakamura H, Nemenoff RA, Gronich JH, Bonventre JV. Subcellular characteristics of phospholipase A2 activity in the rat kidney. Enhanced cytosolic, mitochondrial, and microsomal phospholipase A2 enzymatic activity after renal ischemia and reperfusion. J Clin Invest. 1991;87(5):1810-8.

90. Worrell RT, Bao HF, Denson DD, Eaton DC. Contrasting effects of CPLA2 on epithelial Na + transport. Am J Physiol Cell Physiol. 2001;281(1):C147-56.

91. Filippov A, Skatova G, Porotikov V, Kobrinsky E, Saxon M. Ca2 +-antagonistic properties of phospholipase A2 inhibitors, mepacrine and chloroquine. Gen Physiol Biophys. 1989;8(2):113-8.

92. de la Peña P, Reeves JP. Inhibition and activation of $\mathrm{Na}+-\mathrm{Ca} 2+$ exchange activity by quinacrine. Am J Physiol. 1987;252(1 Pt 1):C24-9.

\section{Submit your next manuscript to BioMed Central and we will help you at every step:}

- We accept pre-submission inquiries

- Our selector tool helps you to find the most relevant journal

- We provide round the clock customer support

- Convenient online submission

- Thorough peer review

- Inclusion in PubMed and all major indexing services

- Maximum visibility for your research

Submit your manuscript at www.biomedcentral.com/submit 